\title{
Papers
}

\section{Mechanical methods of reducing blood transfusion in cardiac surgery: randomised controlled trial}

\author{
Neil McGill, Denise O’Shaughnessy, Ruth Pickering, Mike Herbertson, Ravi Gill
}

\begin{abstract}
Objective To assess the effectiveness of two mechanical methods of blood conservation in reducing the need for allogeneic red blood cells or coagulation products during cardiac surgery.

Design Randomised controlled trial.

Setting Regional cardiac centre in a teaching hospital in Southampton.

Participants 263 adults aged 18-80 years undergoing elective coronary artery bypass surgery entered the study, of whom 252 completed the trial. All patients received routine perioperative care. Patients were allocated to one of three treatment groups: intraoperative cell salvage, intraoperative cell salvage with acute perioperative normovolaemic haemodilution, or no mechanical blood conservation. There were 84 patients in each group.

Main outcome measures Numbers of patients who received allogeneic blood or coagulation products, and the mean number of units of blood transfused per patient.

Results Of the patients in the intraoperative cell salvage group, 26 were given a transfusion of allogeneic blood, compared with 43 in the control group (odds ratio 0.43 (95\% confidence interval 0.23 to 0.80$)$ ). The mean number of units of allogeneic blood transfused per patient in the intraoperative cell salvage group was 0.68 units $(\mathrm{SD}=1.55)$, compared with 1.07 (1.56) units in the control group. 32 of the patients in the intraoperative cell salvage group were given any blood product, compared with 47 in the control group (odds ratio 0.47 (0.25 to 0.89 ); $\mathrm{P}=0.019)$. Combining acute perioperative normovolaemic haemodilution with intraoperative cell salvage conferred no additional benefits.

Conclusions An intraoperative cell salvage device should be used in elective coronary artery bypass grafting. Pharmacological strategies may achieve further reductions in blood transfusions. Yet further reductions in blood transfusions could be achieved if the lower safe limit of haemoglobin concentration in patients undergoing cardiac surgery were known.
\end{abstract}

\section{Introduction}

The National Blood Service for England issues approximately 2.2 million units of blood a year, of which $10 \%$ are used in cardiac surgical units. ${ }^{12}$ Up to $92 \%$ of patients presenting for elective cardiac surgery receive blood. ${ }^{3}$ In our own institution recently this proportion was $82 \% .{ }^{4}$ Patients who receive allogeneic blood risk contracting bloodborne or other infections or having a perioperative myocardial infarction. ${ }^{5-7}$ To minimise the risk of transmission of variant Creutzfeldt-Jakob disease, leucodepletion of all donated blood in this country has been introduced. This has quadrupled the cost of allogeneic red blood cells. The optimal use of this scarce, expensive, and potentially infectious resource is of national importance.

Pharmacological and mechanical methods can reduce the need for transfusion of allogeneic red blood cells and blood coagulation products. The foremost mechanical methods of perioperative conservation of red blood cells are intraoperative cell salvage and acute perioperative normovolaemic haemodilution. Intraoperative cell salvage is the most widely used method in elective cardiac surgery. ${ }^{8}$ Acute perioperative normovolaemic haemodilution is used in less than $20 \%$ of cardiac units. ${ }^{9}$ Both techniques have cost implications and have yet to become normal practice-perhaps due to the lack of data showing their effectiveness. ${ }^{11}$

We hypothesised that during cardiac surgery intraoperative cell salvage would reduce the need for allogeneic red blood cell transfusion, compared with control management, and that combining acute perioperative normovolaemic haemodilution with intraoperative cell salvage would lead to a further reduction.

We report the results of a randomised controlled trial in patients undergoing elective coronary artery bypass surgery. We compared a group of patients in whom intraoperative cell salvage was used with a control group and with a group in whom acute perioperative normovolaemic haemodilution was used in addition to intraoperative cell salvage. The primary outcome measures were the number of patients who were given allogeneic red blood cells and blood coagulation products and the mean number of units of red blood cells transfused per patient. Secondary outcomes were mediastinal drainage of blood, length of intensive care and stay in hospital, and perioperative complications.

\section{Materials and methods}

\section{Selection of patients}

After the study was approved by the local research ethics committee, patients were approached on their admission the day before surgery in the cardiac unit at

\section{S Mott Children's Hospital, Section of Pediatric Anesthesiology, Room F3900, Box 0211, Ann Arbor, MI 48109-0211, USA \\ Neil McGill visiting instructor \\ Department of Haematology, Southampton University Hospitals NHS Trust, Southampton SO16 6YD \\ Denise \\ O'Shaughnessy \\ consultant \\ haematologist \\ Medical Statistics Group, \\ Southampton \\ University Hospitals NHS Trust \\ Ruth Pickering \\ lecturer in medical statistics \\ Shackleton Department of Anaesthesia, Southampton University Hospitals NHS Trust \\ Mike Herbertson consultant cardiac anaesthetist \\ Ravi Gill consultant cardiac anaesthetist \\ Correspondence to: R Gill ravi.gill@suht. swest.nhs.uk}

bmj.com 2002;324:1299 


\section{Eligibility criteria}

Inclusion criteria:

- Age 18-80 years

- Ejection fraction $>30 \%$

- Serum creatinine concentration $<150 \mu \mathrm{mol} / \mathrm{l}$

- International normalised ratio and activated partial

thromboplastin time $<1.5$

- Platelet count $>150 \times 10^{9} / 1$

- Haemoglobin concentration $>120 \mathrm{~g} / \mathrm{l}$

- Haematocrit $>0.36$

- Weight $>60 \mathrm{~kg}$

Exclusion criteria:

- Emergency operation

- Redo procedures and multiple procedures

- Known carotid stenosis $>50 \%$

- Myocardial infarction in past three weeks

- Heparin or warfarin taken in previous five days

- Antiplatelet treatment other than aspirin

- Cerebrovascular disease

- History of liver disease

- Jehovah's Witnesses

Southampton General Hospital. Written informed consent was sought from all patients thought to meet the inclusion criteria (box).

\section{Sample size}

We made two comparisons between groups: between the intraoperative cell salvage group and the control group, and between the intraoperative cell salvage group and the group that received both intraoperative cell salvage and acute perioperative normovolaemic haemodilution (combined treatment). With the incorporation of a Bonferroni correction, results would be deemed significant if they achieved a $\mathrm{P}$ value of $<0.025$. Thus 80 patients would be needed in each group for the trial to have a power of $80 \%$ in reducing the percentage of patients receiving blood from $82 \%$ to $60 \%$. Because patients were randomised to the six participating surgeons, recruiting an equal number of patients for each surgeon led to the eventual number of 84 in each group.

\section{Randomisation and masking}

Patients who met the inclusion criteria were randomised to one of the three groups. The allocations were generated from random number tables by an independent observer and concealed in sealed opaque envelopes. Randomisation was stratified across the six participating surgeons, who had different strategies for preoperative aspirin cessation, administration of antifibrinolytic treatment, and myocardial preservation. Intraoperative masking of mechanical red blood cell salvage treatment was not possible.

Flow of patients through the trial

A total of 263 patients who were thought to be eligible for trial entry consented to take part (fig 1). Seven of these patients were found to meet the exclusion criteria. Two patients who consented to take part could not be included because cell salvage or blood harvest machines were not available. Another two patients were excluded because of inappropriate perioperative transfusion. These four patients were not included in the analysis because of insufficient data. They were replaced with other patients in the trial who were randomised by the independent observer so that their next allocation was concealed. No other violations of the trial protocol occurred. A total of 252 patients were included in the statistical analyses. All patients survived to discharge from hospital.

\section{Trial protocol}

Management of patients before cardiopulmonary bypass All patients received standard premedication and anaesthesia. In all groups intravenous fluids and intravenous boluses of phenylephrine $(50-100 \mu \mathrm{g})$ were used to maintain invasively monitored arterial blood pressure to within $20 \%$ of preoperative values. In the operating room antifibrinolytic treatment and choice of myocardial preservation remained at the discretion of the surgeon. All patients received anticoagulation treatment of $3 \mathrm{mg} / \mathrm{kg}$ of intravenous heparin to achieve an activated clotting time of $>400 \mathrm{~s}$, with an additional $1 \mathrm{mg} / \mathrm{kg}$ intravenous bolus to treat an activated clotting time of $<400 \mathrm{~s}$.

Intraoperative cell salvage group A cell saver (Dideco Compact, Dideco, Mirandola, Italy) was used from incision until the end of surgery.

\section{Intraoperative cell salvage}

Usually during surgery blood from the site of the operation is suctioned and discarded. In intraoperative cell salvage all shed blood is suctioned to a storage system, and heparin is added to prevent thrombus formation. At the termination of cardiopulmonary bypass, blood remaining in the bypass circuit is added to that in the storage system. This fluid is then centrifuged to leave a solution of red blood cells with a haematocrit of 0.5-0.6. This solution of homologous blood is then retransfused into the patient.

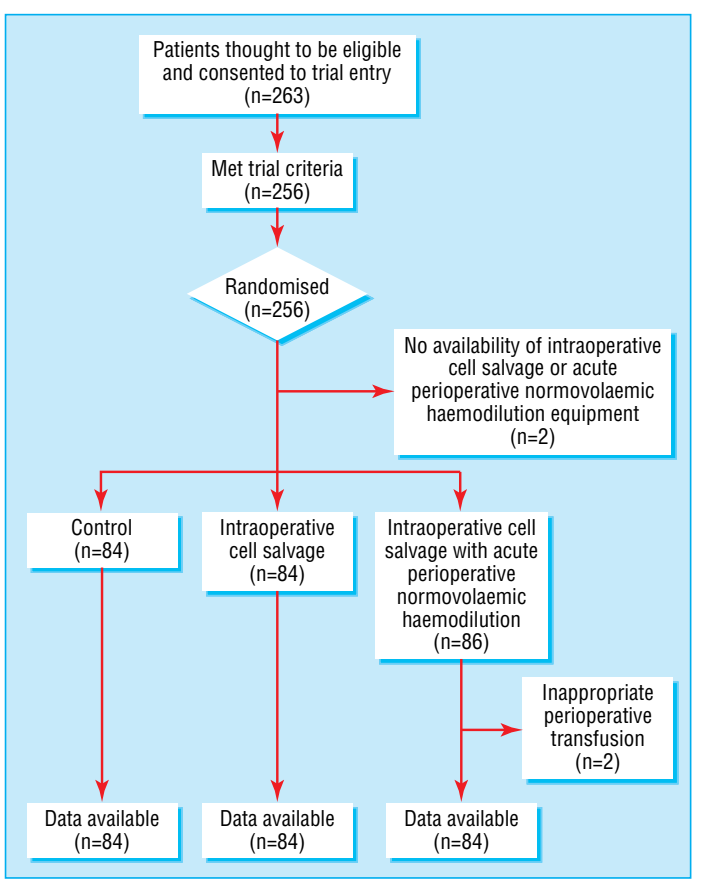

Fig 1 Flow of patients through the trial 
Combined treatment group After induction of anaesthesia $10 \mathrm{ml} / \mathrm{kg}$ of blood was removed from the central venous line while being replaced at the same time with an equivalent volume of modified gelatin (Gelofusine). The Harvest Blood Stream Recovery System, an autologous recovery system, was used to remove blood. The recovered blood was stored at room temperature.

\section{Acute perioperative normovolaemic haemodilution}

After induction of anaesthesia blood is removed from the patient and is replaced with an equivalent volume of colloid. The blood is anticoagulated during removal to prevent thrombus formation. This blood has a haematocrit equal to that of the patient, usually $0.35-0.45$. The blood is labelled and stored during the operation. After the termination of bypass the patient's haematocrit will usually be considerably lower than that of the stored blood. This blood is then retransfused, so increasing the patient's haematocrit.

Management of patients during cardiopulmonary bypass All groups were managed identically during cardiopulmonary bypass. The cardiopulmonary bypass circuit was primed with $2 \mathrm{l}$ of crystalloid solution. Cardiopulmonary bypass flows were $2.4 \mathrm{l} / \mathrm{min} / \mathrm{m}^{2}$. If a patient's haematocrit fell below 0.2 , blood was added to the circuit. Moderate hypothermia was used to lower the patient's temperature to $32^{\circ} \mathrm{C}$. Mean arterial pressures were maintained at $50-80 \mathrm{~mm} \mathrm{Hg}$.

\section{Management after cardiopulmonary bypass}

After the termination of the bypass all patients received intravenous protamine to neutralise circulating heparin. The dose of protamine matched that of the pre-bypass dose of heparin weight for weight.

Control group The residual cardiopulmonary bypass circuit volume was retransfused into the patient after protamine administration.

Intraoperative cell salvage group After protamine administration any shed blood and the residual cardiopulmonary bypass circuit volume were washed and centrifuged by the intraoperative cell salvage machine then retransfused.

Combined treatment group After protamine administration the autologous blood collected after induction of anaesthesia was retransfused. The cell saver was used in the same manner as in the intraoperative cell salvage group.

\section{Intensive care}

All patients were under the care of cardiac intensivists, who were blind to the allocation of patients to study group. The surgical team was involved only when further surgical issues arose. The threshold for transfusion of allogeneic red blood cells was the same in all groups: haemoglobin concentration $<90 \mathrm{~g} / \mathrm{l}$ and haematocrit $<0.27$. Administration of allogeneic blood coagulation products (fresh frozen plasma and platelets) was at the discretion of the cardiac intensivists.
Table 1 Characteristics of patients ( $n=84$ in each group) before their operation. Values are numbers (\%) of patients, unless stated otherwise

\begin{tabular}{lccc} 
& Control & $\begin{array}{c}\text { Intraoperative } \\
\text { cell salvage }\end{array}$ & $\begin{array}{c}\text { Combined } \\
\text { treatment* }\end{array}$ \\
\hline Men & $74(88)$ & $75(89)$ & $74(88)$ \\
\hline Age (years): & & & \\
\hline Mean (SD) & $63.4(9.1)$ & $63.8(7.8)$ & $63.1(8.2)$ \\
\hline Range & $44-80$ & $42-78$ & $37-77$ \\
\hline Weight (kg) & & \\
\hline Mean (SD) & $83.1(11.2)$ & $84.5(11.7)$ & $84.3(11.5)$ \\
\hline Range & $63-111$ & $61-114$ & $65-120$ \\
\hline Parsonnet score† & & & \\
\hline Mean (SD) & $5.8(5.4)$ & $5.6(4.6)$ & $0-14$ \\
\hline Range & $0-23$ & $0-23$ & $63(75)$ \\
\hline Left ventricular function: & & $67(80)$ & $21(25)$ \\
\hline Good & $69(82)$ & $17(20)$ & $33(39)$ \\
\hline Moderate & $15(18)$ & $26(31)$ &
\end{tabular}

${ }^{*}$ Intraoperative cell salvage with acute perioperative normovolaemic haemodilution. †0=low risk, $25=$ high risk.

\section{Statistical analysis}

Percentages of patients receiving the various blood products were compared in logistic regression models, controlled for surgeon. Differences between groups in these percentages were deemed significant if they achieved significance of $\mathrm{P}<0.025$ in the Wald test. The Kruskal-Wallis one way analysis of variance was used to compare the differences between the groups in the amounts of blood products used and in the secondary outcomes.

\section{Results}

\section{Baseline characteristics}

The distributions of sex, age, weight, left ventricular function, and aspirin administration were similar across the three groups (table 1). Parsonnet scores, which reflect a number of patient variables and allow preoperative risk stratification, were also similar across the groups.

\section{Primary outcomes}

Table 2 describes the differences in primary outcomes between the groups.

\section{Comparison of intraoperative cell salvage and control treatment}

Of the 84 patients in the intraoperative cell salvage group, 26 were given allogeneic red blood cells, compared with 43 in the control group (odds ratio 0.43 (95\% confidence interval 0.23 to 0.80 ); $\mathrm{P}=0.008$ ). The mean number of units of allogeneic red blood cells transfused per patient in the intraoperative cell salvage group was 0.68 , compared with 1.07 units in the control group. The number of patients in the intraoperative cell salvage group who were given any blood product was 32, compared with 47 in the control group (odds ratio 0.47 (0.25 to 0.89 ); $\mathrm{P}=0.019$ ).

\section{Comparison of intraoperative cell salvage and combined} treatment

The combination of acute perioperative normovolaemic haemodilution and intraoperative cell salvage did not show any additional benefit over intraoperative cell salvage alone in relation to the number of patients needing allogeneic red blood cell transfusion, the 
Table 2 Blood products given to patients ( $\mathrm{n}=84$ in each group) during their perioperative course

\begin{tabular}{|c|c|c|c|c|c|c|c|c|}
\hline \multirow[b]{2}{*}{ Blood product received } & \multirow[b]{2}{*}{ Control } & \multirow[b]{2}{*}{$\begin{array}{l}\text { Intraoperative cell } \\
\text { salvage }\end{array}$} & \multirow[b]{2}{*}{$\begin{array}{l}\text { Combined } \\
\text { treatment }\end{array}$} & \multirow[b]{2}{*}{$\begin{array}{l}\text { Kruskal-Wallis } \\
\mathrm{P} \text { value }\end{array}$} & \multicolumn{2}{|c|}{$\begin{array}{l}\text { Intraoperative cell salvage } \\
\text { v control }\end{array}$} & \multicolumn{2}{|c|}{$\begin{array}{l}\text { Combined treatment } v \text { intraoperative } \\
\text { cell salvage }{ }^{*}\end{array}$} \\
\hline & & & & & Odds ratio $(95 \% \mathrm{CI})$ & $\begin{array}{l}\text { Wald test } \\
P \text { value }\end{array}$ & Odds ratio $(95 \% \mathrm{CI})$ & $\begin{array}{l}\text { Wald test } \\
P \text { value }\end{array}$ \\
\hline \multicolumn{9}{|l|}{ Allogeneic blood: } \\
\hline No of patients & 43 & 26 & 29 & & $0.43(0.23-0.80)$ & 0.008 & $1.18(0.62-2.24)$ & 0.622 \\
\hline $\begin{array}{l}\text { Mean }(S D) \text { No of units } \\
\text { received per patient }\end{array}$ & $1.07(1.56)$ & $0.68(1.55)$ & $0.63(1.22)$ & 0.015 & & & & \\
\hline Range & $0-8$ & $0-11$ & $0-8$ & & & & & \\
\hline \multicolumn{9}{|l|}{ Fresh frozen plasma: } \\
\hline No of patients & 13 & 14 & 13 & & $1.1(0.47-2.53)$ & 0.831 & $0.91(0.40-2.11)$ & 0.831 \\
\hline $\begin{array}{l}\text { Mean }(S D) \text { No of units } \\
\text { received per patient }\end{array}$ & $0.49(1.25)$ & $0.57(1.47)$ & $0.43(1.12)$ & 0.952 & & & & \\
\hline Range & $0-6$ & $0-8$ & $0-6$ & & & & & \\
\hline \multicolumn{9}{|l|}{ Platelets: } \\
\hline No of patients & 15 & 11 & 15 & & $0.68(0.29-1.62)$ & 0.386 & $1.46(0.62-3.47)$ & 0.386 \\
\hline $\begin{array}{l}\text { Mean }(S D) \text { No of units } \\
\text { received per patient }\end{array}$ & $0.29(0.67)$ & $0.20(0.62)$ & $0.31(0.81)$ & 0.601 & & & & \\
\hline $\begin{array}{l}\text { No of patients given any } \\
\text { blood product }\end{array}$ & 47 & 32 & 33 & & $0.47(0.25-0.89)$ & 0.019 & $1.05(0.56-1.98)$ & 0.872 \\
\hline
\end{tabular}

mean number of units of allogeneic red blood transfused per patient, or the number of patients who were given any allogeneic blood product.

Most patients were not given allogeneic blood (fig 2). Fifty one patients received one unit of blood,

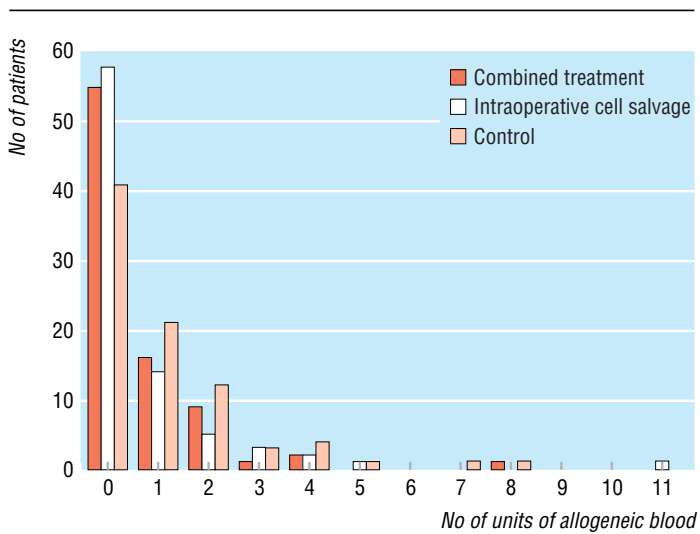

Fig 2 No of units of allogeneic blood transfused into patients

Table 3 Haemoglobin concentrations $(\mathrm{g} / \mathrm{l})$ at different stages of patients' stay in hospital ( $n=84$ in each group)

\begin{tabular}{lccc} 
Stage & Control group & $\begin{array}{c}\text { Intraoperative } \\
\text { cell salvage }\end{array}$ & Combined treatment \\
\hline Before operation: & 142 & 145 & 145 \\
\hline Median & $135-50$ & $136-50$ & $138-50$ \\
\hline Interquartile range & $122-64$ & $125-60$ & $124-66$ \\
\hline Range (min-max) & 100 & 105 & 108 \\
\hline On admission to intensive care unit: & $91-107$ & $98-116$ & $99-116$ \\
\hline Median & $67-133$ & $77-160$ & $78-137$ \\
\hline Interquartile range & & & 105 \\
\hline Range (min-max) & 100 & $95-115$ & $96-113$ \\
\hline Day 1 after operation: & $94-109$ & $84-153$ & \\
\hline Median & $85-123$ & & 108 \\
\hline Interquartile range & & 105 & $82-136$ \\
\hline Range (min-max) & 106 & $98-115$ & \\
\hline Day 3 after operation: & $98-112$ & $75-146$ & \\
\hline Median & $86-154$ & & \\
\hline Interquartile range & & \\
\hline Range (min-max) & & \\
\hline
\end{tabular}

and 25 received two. Nine patients needed a markedly higher amount of transfused blood ( $\geqslant 3$ units). These patients were returned to the operating theatre for re-exploration of the mediastinum. A surgical cause of bleeding was found in seven of these patients (three in the control group and two each in the intraoperative cell salvage group and the combined treatment group).

The variations in haemoglobin concentration from before the operation to day 3 after the operation were similar in the three groups (table 3). No patient was given a transfusion of allogeneic blood after leaving the intensive care unit.

\section{Secondary outcomes}

Table 4 shows the differences between the groups in the secondary outcomes. There were no differences between the groups in mediastinal drainage, time in intensive care, or length of stay in hospital. Table 5 shows perioperative variables in the three groups. Patients in the combination treatment group spent the longest time in the anaesthetic room. The median duration of acute perioperative normovolaemic haemodilution was 13 minutes. Groups were similar with respect to total anaesthesia and surgery times, and times on cardiopulmonary bypass and with the aorta cross-clamped. Perioperative complications were evenly distributed across the groups (table 6).

\section{Discussion}

Intraoperative cell salvage significantly reduced the number of patients who were given allogeneic red blood cells or blood coagulation products during elective coronary artery bypass grafting, compared with patients who were operated on without any mechanical blood conservation technique. There was a corresponding reduction in the mean number of units of allogeneic red blood cells used. However, our hypothesis that the addition of acute perioperative normovolaemic haemodilution to intraoperative cell salvage would confer additional benefit was not supported. 
Table 4 Secondary outcomes ( $n=84$ in each group)

\begin{tabular}{|c|c|c|c|c|}
\hline & Control & Intraoperative cell salvage & Combined treatment & $\begin{array}{c}\text { Kruskal-Wallis } \\
\text { P value }\end{array}$ \\
\hline \multicolumn{5}{|c|}{ Mean mediastinal drainage (ml/hour): } \\
\hline Mean (SD) & $39.5(18.8)$ & $41.0(19.9)$ & $42.4(23.6)$ & 0.580 \\
\hline Median & 36.0 & 37.7 & 37.9 & \\
\hline Interquartile range & $26.4-46.6$ & $28.5-46.7$ & $27.9-52.0$ & \\
\hline Range (min-max) & $7.1-90.8$ & $15.8-143.0$ & $13.7-195.0$ & \\
\hline \multicolumn{5}{|c|}{ Total mediastinal drainage $(\mathrm{ml})$ : } \\
\hline Mean (SD) & $795.8(443.9)$ & $821.6(477.3)$ & $851.8(526.2)$ & 0.644 \\
\hline Median & 700.0 & 760.0 & 695.0 & \\
\hline Interquartile range & $505-908$ & $525-920$ & $525-1040$ & \\
\hline Range (min-max) & $120-2180$ & $260-3420$ & $260-4100$ & \\
\hline \multicolumn{5}{|c|}{ Time in intensive care (hours): } \\
\hline Median & 22.9 & 22.7 & 23.3 & 0.249 \\
\hline Interquartile range & $21.8-24.5$ & $22.0-24.6$ & $22.5-25.0$ & \\
\hline Range (min-max) & $15.5-72.9$ & $18.3-166.3$ & $16.6-122.0$ & \\
\hline \multicolumn{5}{|c|}{ Length of hospital stay (hours): } \\
\hline Median & 168.9 & 160.7 & 170.4 & 0.724 \\
\hline Interquartile range & $140.3-219.3$ & $145.5-198.8$ & 147.1-221.6 & \\
\hline Range (min-max) & $101.2-989.0$ & $122.7-766.9$ & $103.6-773.4$ & \\
\hline
\end{tabular}

\section{Intraoperative cell salvage}

Our results are consistent with other published work. A recent meta-analysis of cell salvage in cardiac and orthopaedic surgery found that in cardiac surgery cell salvage marginally reduced use of allogeneic blood products (relative risk 0.85 (0.79 to 0.92$)) .{ }^{10}$ However, none of the trials washed the salvaged blood before returning it to the patient, and the intraoperative cell salvage devices were used only postoperatively. Trials in which intraoperative cell salvage machines were used intraoperatively failed to meet standard eligibility criteria for the meta-analysis. Our method of intraoperative cell salvage maximised surgical salvage of red blood cells, and our washing of the residual cardiopulmonary bypass volume allowed optimal haemoconcentration, accounting for the greater efficacy of intraoperative cell salvage. Our study is the first to compare intraoperative use of intraoperative cell salvage with control treatment.

Acute perioperative normovolaemic haemodilution Acute perioperative normovolaemic haemodilution is not well established in cardiac surgery. A meta-analysis of the treatment across surgical specialties concluded that it reduces the need for allogeneic red blood cells (odds ratio 0.31 (0.15 to 0.62)), but that the evidence in cardiac surgery was less compelling (0.51 (0.26 to $0.99)){ }^{11}$ This meta-analysis included 11 randomised controlled trials in cardiac surgery. ${ }^{12-22}$ However, the quality of the evidence from these trials varied, only four of the trials having a transfusion protocol. ${ }^{17} 182122$ Overall the evidence for the benefit of acute perioperative normovolaemic haemodilution in reducing use of allogeneic red blood cells during cardiac surgery was equivocal.

Our study was designed to look at the additional benefit that acute perioperative normovolaemic haemodilution might give over intraoperative cell salvage alone. Our results indicate that acute perioperative normovolaemic haemodilution does not confer additional benefits in terms of reduced use of allogeneic transfusion (odds ratio 1.05 (0.56 to 1.98)). This may be because not enough blood was removed at the start of the procedure. Given the patients' severe coronary artery disease, we decided not to exceed a predonated volume of $10 \mathrm{ml} / \mathrm{kg}$ Removing a greater volume of blood preoperatively may expose patients to ischaemic events and decreased myocardial contractility. ${ }^{23}$

Table 5 Perioperative data for patients undergoing coronary artery bypass surgery ( $n=84$ in each group). Figures are minutes unless stated otherwise

\begin{tabular}{|c|c|c|c|}
\hline & Control & Intraoperative cell salvage & Combined treatment \\
\hline \multicolumn{4}{|c|}{ Time from induction to theatre: } \\
\hline Median & 25 & 26 & 34 \\
\hline Interquartile range & $22-28$ & $23-30$ & $27-38$ \\
\hline Range (min-max) & $13-85$ & $15-70$ & $20-60$ \\
\hline \multicolumn{4}{|c|}{ Time to complete acute perioperative nomovolaemic haemodilution: } \\
\hline Median & - & - & 13 \\
\hline Interquartile range & - & - & $11-17$ \\
\hline Range (min-max) & - & - & $6-30$ \\
\hline \multicolumn{4}{|c|}{ Time aortic cross clamp used: } \\
\hline Median & 39 & 39 & 29 \\
\hline Interquartile range & $32-50$ & $30-48$ & $23-37$ \\
\hline Range (min-max) & $11-84$ & $16-74$ & $12-85$ \\
\hline \multicolumn{4}{|c|}{ Time on cardiopulmonary bypass: } \\
\hline Median & 66 & 67 & 63 \\
\hline Interquartile range & $56-83$ & $55-85$ & $53-80$ \\
\hline Range (min-max) & $25-155$ & $34-121$ & $31-132$ \\
\hline \multicolumn{4}{|l|}{ Time in surgery: } \\
\hline Median & 160 & 160 & 154 \\
\hline Interquartile range & $135-196$ & $140-184$ & $131-174$ \\
\hline Range (min-max) & $100-265$ & $110-250$ & $97-264$ \\
\hline \multicolumn{4}{|l|}{ Time under anaesthetic: } \\
\hline Median & 200 & 199 & 203 \\
\hline Interquartile range & 179-230 & $176-226$ & 179-222 \\
\hline Range (min-max) & $135-319$ & $102-305$ & $134-333$ \\
\hline \multicolumn{4}{|c|}{ Antifibrinolytic treatment: } \\
\hline No of patients & 33 & 33 & 33 \\
\hline
\end{tabular}

Table 6 Numbers of patients with perioperative complications ( $n=84$ in each group)

\begin{tabular}{lccc} 
& Control & Intraoperative cell salvage & Combined treatment \\
\hline Without complications & 42 & 46 & 46 \\
\hline Inotropes required after 24 hours & 9 & 12 & 11 \\
\hline Surgical bleeding & 3 & 2 & 2 \\
\hline Cerebrovascular accident & 2 & 1 & 1 \\
\hline Arrhythmias & 27 & 17 & 20 \\
\hline Renal failure & 0 & 1 & 2 \\
\hline Proven infection & 7 & 11 & 7 \\
\hline Myocardial infarction & 10 & 5 & 4
\end{tabular}


What is already known on this topic

Patients undergoing elective coronary artery bypass surgery often need a blood transfusion

Recent meta-analyses have shown that the mechanical blood conservation techniques of intraoperative cell salvage and acute perioperative normovolaemic haemodilution may reduce the need for transfusion, but flawed methods in trials mean that clear evidence in cardiac surgery is lacking

\section{What this study adds}

Intraoperative cell salvage significantly reduces the number of patients needing an allogeneic blood transfusion

Combining acute perioperative normovolaemic haemodilution with intraoperative cell salvage does not confer any additional benefit

\section{Limitations}

Just over half $(43 / 84)$ the patients in the control group were given a transfusion-a considerably lower proportion than that reported for our institution in a previous study. ${ }^{4}$ We believe the main reason for this was that the transfusion threshold was reduced between the two studies from a haemoglobin concentration of $100 \mathrm{~g} / \mathrm{l}$ to $90 \mathrm{~g} / \mathrm{l}$.

The lack of a protocol on the use of allogeneic blood coagulation products means that caution is needed in interpreting differences between the groups in the use of fresh frozen plasma and platelets. Our trial involved patients undergoing elective coronary artery bypass grafting. Although intraoperative cell salvage may be useful in more complex cardiac surgery or for patients with pre-existing coagulopathy, our findings cannot necessarily be extrapolated to such patients.

Intraoperative masking of mechanical conservation technique was not possible. This might have led to transfusion practice being driven by knowledge of allocation to group. This effect would be pronounced if no transfusion protocol were used. Our finding of a decrease in the number of patients who received a transfusion of allogeneic red blood cells may be related to the haemoglobin concentration that is used as the transfusion threshold, the efficacy of intraoperative cell salvage, or transfusion practices. Because the intensive care staff were blinded to allocation to group, and no protocol violations occurred, we can assume that the reduction in allogeneic red blood cell transfusion is related to the efficacy of intraoperative cell salvage.

\section{Conclusions}

The need for allogeneic red blood cell transfusion in elective coronary artery bypass grafting can be reduced by using intraoperative cell salvage. Acute perioperative normovolaemic haemodilution with intraoperative cell salvage confers no additional benefit. We believe a transfusion rate of $31 \%$ of patients undergoing elective coronary artery bypass grafting is still unacceptable. The lower safe limit of haemoglobin concentration in patients undergoing cardiac surgery- either while they are on bypass or postoperatively-is unknown. If this limit was known, and made use of, the combination of optimal pharmacological strategies with intraoperative cell salvage could achieve yet further reductions in the numbers of patients who need to be given transfusions of allogeneic red blood cells and blood coagulation products.

Mr S Yates, manager of Haematology and Transfusion Laboratories, provided essential laboratory and transfusion support, without which this study could not have occurred. Dr D C Smith, consultant cardiac anaesthetist, reviewed the paper and made helpful comments.

Contributors: RG had the original idea. RG, MH, DO'S, and RMP designed the study and obtained funding. NM, RG, and MH collected data. NM and RMP carried out data analysis. NM, $\mathrm{RG}$, and MH prepared the manuscript, which was reviewed by all authors. RG is the guarantor.

Funding: This study was supported by a grant from the local blood transfusion service.

Competing interests: None declared.

1 National Blood Authority. Annual report 2000. www.blood.co.uk/pages/ f24Pubs.html

2 Killip T. Twenty years of coronary bypasss surgery. $N$ Engl J Med 1988;319:366-8.

3 Renton MC, McClelland DB, Sinclair CJ. Use of blood products in cardiac surgery. Perfusion 1997;3:157-62.

4 Dalrymple-Hay MJ, Pack L, Deakin CD, Shephard S, Ohri SK, Haw MP, et al. Autotransfusion of washed shed mediastinal fluid decreases the requirement for autologous blood transfusion following cardiac surgery: a prospective randomised trial. Eur J Cardiothorac Surg 1999;15:830-4.

5 Schreiber G, Busch M, Kleinman S, Korelitz J. The risk of transfusion-transmitted viral infections. N Engl J Med 1996;334:1685-90.

6 Duffy G, Neal KR. Differences in post-operative infection rates between patients receiving autologous and allogeneic blood transfusion: a meta-analysis of published randomised and nonrandomised studies. Transfus Med 1996;6:325-8.

7 Spiess BD, Ley C, Body SC, Siegel LC, Stover EP, Maddi R, et al. Hematocrit value on intensive care unit entry influences the frequency of $\mathrm{Q}$-wave myocardial infarction after coronary artery bypass grafting. The Institutions of the Multicenter Study of Perioperative Ischemia (McSPI) Research Group.J Thorac Cardiovasc Surg 1998;116:460-7

8 Henry DA, Henderson KM, Fryer JL, Treloar CJ, McGrath KM, Deveridge SF. Use of interventions to minimise perioperative allogeneic blood transfusion in Australia. Med J Aust 2000;172:365-9.

9 Fergusson D, Blair A, Henry D, Hisashige A, Huet C, Koopman-van Gemert AW, et al. Technologies to minimise blood transfusion in cardiac and orthopaedic surgery: results of a practice variation survey in nine countries. International Study of Peri-operative Transfusion (ISPOT) Investigators. Int J Technol Assess Health Care 1999;15:717-28.

10 Huet C, Salmi LR, Fergusson D, Koopman-van Gemert AW, Rubens F, Laupacis A. A meta-analysis of the effectiveness of cell salvage to minimize perioperative allogenic blood transfusion in cardiac and ortho-
pedic surgery. International Study of Peri-operative Transfusion (ISPOT) pedic surgery. International Study of Peri-ope
Investigators. Anesth Analg 1999;89:861-9.

11 Bryson GL, Laupacis A, Wells GA. Does acute normovolaemic haemodilution reduce perioperative allogeneic transfusion? A meta-analysis. The International Study of Peri-operative Transfusion. Anesth Analg 1998;86:9-15.

12 Hallowell P, Bland JHL, Buckley MJ, Lowenstein E. Transfusion of fresh autologous blood in open heart surgery: a method of reducing bank blood requirements. Thorac Cardiovasc Surg 1972;64:941-8.

13 Lawson NW, Ochsner JL, Mills NL, Leonard GL. The use of hemodilution and fresh autologous blood in open-heart surgery. Anesth Analg 1974;53:672-83.

14 Kaplan JA, Cannarella C, Jones EL, Kutner MH, Hatcher CR Jr, Dunbar RW. Autologous blood transfusion during cardiac surgery: a re-evaluation of three methods. Thorac Cardiovasc Surg 1977;74:4-10.

15 Lilleaasen P. Moderate and extreme haemodilution in open-heart surgery: blood requirements, bleeding and platelet counts. Scand J Thorac Cardiovasc Surg 1977;11:97-103.

16 Dale J, Lilleaasen P, Erikssen J. Hemostasis after open-heart surgery with extreme or moderate hemodilution. Eur Surg Res 1987;19:339-47.

17 Dietrich W, Barankay A, Dilthey G, Mitto HP, Richter JA. Reduction of blood utilisation during myocardial re-vascularisation. Thorac Cardiovasc Surg 1989;97:213-9.

18 Boldt J, Kling D, Weidler B, Zickmann B, Herold C, Dapper F, et al. Acute preoperative hemodilution in cardiac surgery: volume replacement with a hypertonic saline-hydroxyethyl starch solution. J Cardiothorac Vasc Anesth 1991:5:23-8.

19 Vedrinne C, Girard C, Jegaden O, Blanc P, Bouvier H, Ffrench P, et al. Reduction in blood loss and blood use after cardiopulmonary bypass with high-dose aprotonin versus autologous fresh whole blood transfusion. J Cardiothorac Vasc Anesth 1992;6:319-23.

20 Herregods L, Foubert L, Moerman A, Francois K, Rolly G. Comparative study of limited intentional normovolaemic haemodilution in patients with left main coronary artery stenosis. Anaesthesia 995;50:950-3. 
21 Triulzi DJ, Gilmor GD, Ness PM, Baumgartner WA, Schultheis LW. Efficacy of autologous fresh whole blood or platelet-rich plasma in adult cardiac surgery. Transfusion 1995;35:627-34.

22 Kochamba GS, Pfeffer TA, Sintek CF, Khonsari S. Intraoperative autotransfusion reduces blood loss after cardiopulmonary bypass. Ann Thorac Surg 1996;61:900-3.
23 Rao TKL, Montoya A. Cardiovascular, electrocardiographic and respiratory changes following acute anemia with volume replacement in patients with coronary artery disease. Anesthesiol Rev 1985;12:49-54.

(Accepted 5 December 2001)

\section{Science commentary: Why is it important to reduce the need for blood transfusion, and how can it be done?}

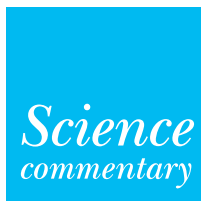

Abi Berger science editor, BMJ
Reducing the need for blood transfusions is desirable for several reasons. Since 2000 in the United Kingdom it has been mandatory to remove all white cells from donated blood to reduce the small but theoretical risk of prion disease (variant Creutzfeldt-Jakob disease). This has trebled the cost of providing donated blood. Transmission of hepatitis B, hepatitis C, and HIV by transfusion occurs in 1 in 300000 cases, despite screening programmes. ${ }^{1}$ However, non-fatal but serious transfusion errors occur in 1 in 16000 transfusions. ${ }^{1}$

Critically ill patients are now known to do just as well with a lower haemoglobin concentration than previously thought, thus reducing the need for top-up transfusions. $^{2}$ There is also some evidence that homologous blood transfusions increase the rates of recurrence of some cancers (tumours of the bowel and oesophagus, in particular) and can increase the incidence of wound infections. ${ }^{3}$ It is unclear why these phenomena occur.

A number of mechanical methods have been developed to help reduce the need for postoperative blood transfusions. In the United States erythropoetin injections or autologous blood donations (or both), given preoperatively, are commonly used. Both require the exact date of surgery to be known-but neither process is free from human error in labelling, storing, and administration.

Perioperative dilution and intraoperative blood salvage techniques (such as those described in this paper) are gaining credence, particularly for patients undergoing cardiac and orthopaedic surgery. But neither of these processes is suitable for patients with infection or malignant disease.

After surgery, devices are available to collect blood from wound drains, which can then be retransfused back into the patient. Such techniques reduce the formation of haematomas, but few studies of their efficacy are available, and the techniques are not in general use. ${ }^{4}$

1 Williamson L, Cohen H, Love E, Jones H, Todd A, Soldan K, et al. The Serious Hazards of Transfusion (SHOT) Initiative. Vox Sang 2000;78(suppl 2):291-5.

2 Hebert PC, Wells G, Blajchman MA, Marshall J, Martin C, Pagliarello G, et al. A multicenter, randomized, controlled clinical trial of transfusion requirements in critical care. Transfusion Requirements in Critical Care Investigators, Canadian Critical Care Trials Group. $N$ Engl J Med 1999:340:409-17.

3 Tang R, Chen HH, Wang YL, Changchien CR, Chen JS, Hsu KC, et al. Risk factors for surgical site infection after elective resection of the colon and rectum: a single-center prospective study of 2,809 consecutive patients. Ann Surg 2001;234:181-9.

4 Parker MJ, Roberts C. Closed suction surgical wound drainage after orthopaedic surgery Cochrane Database Syst Rev 2001;4:CD001825. 